Studies in African Lingusitics

Volume 20, Number 2, August 1989

\title{
PHONOLOGICAL PROCESSES IN THE NOUN CLASS SYSTEM OF LAMA*
}

\author{
Meterwa A. Ourso \\ University of Illinois \& Université du Bénin
}

\begin{abstract}
The purpose of this paper is to account for the phonological processes taking place within noun classes and across noun classes in Lama, particularly when some class suffixes are attached to noun stems. This study is therefore an overview of the noun class phonology. After an introduction to the phonology and to the noun class system, we will examine specific phonological problems. It will be shown that when some root final sounds are in contact with some suffixes, they undergo structural changes, namely, assimilation, vowel truncation, and root controlled vowel harmony.
\end{abstract}

\section{Introduction}

In this paper, we attempt to provide a phonological analysis of the processes involved in the affixation within noun classes and across noun classes in Lama. The analysis distinguisthes between phonological rules and morphological rules. The discussion will ony include morhological rules or facts when they prove necessary for the understanding of the phonological problems under focus.

To account for the various phonological problems presented by the data, the paper adopts the general framework of generative phonology; we do not, however, restrict ourself to one specific theory of this framework; we combine the linear approach with the autosegmental one to account for various data. For instance, vowel harmony, as discussed here, is handled in a more elegant way

\footnotetext{
* This paper has undergone several stages and through each stage it has benefited from the comments, suggestions, and criticisms of many friends; we are indebted to those people; we are thankful to M. Kenstowicz, C. Kisseberth, and C. Ulrich for their illuminating comments. We are particularly indebted to R.G. Schuh and to an anonymous reviewer of Studies in African Linguistics. Of course, all the shortcomings of this paper are the writer's responsibility.
} 
within the autosegmental framework as addressed in Clements [1981], Pulleyblank [1986], inter alia.

After a short presentation of the main features in Lama phonology, we introduce and discuss the noun class system. We then concentrate mainly on the analysis of the phonological processes within that noun class system. The analysis attempts to establish the following:

1. Some noun class suffixations trigger phonological processes such as consonant assimilation and dissimilation, vowel truncation, and root controlled ATR vowel harmony.

2. The underlying structure of certain noun stems can best be understood through a comparison between classes, i.e. the structure of a noun in the singular (in Class 1, for instance) is best understood through its structure in the corresponding plural class (Class 2).

3. Although some phonological rules operate across the whole language, certain rules (vowel truncation, for instance) are mostly restricted to noun classes.

The following transcription conventions will be adopted for the present study:

(1) Transcription Conventions

$$
\begin{array}{rlll}
/ / & = & \text { phoneme } \\
{[]} & = & \text { allophone } \\
\partial & = & {[\text { ATR }] \text { schwa }} \\
3 & = & {[- \text { ATR }] \text { schwa }} \\
\# \# & = & \text { underlying representation of a word } \\
\$ & = & \text { syllable boundary } \\
-\quad & = & \text { morpheme boundary } \\
\sim & = & \text { nasalization in vowels } \\
{[\mathrm{d}]} & = & \text { retroflex stop } \\
\sim & = & \text { high tone } \\
\sim & = & \text { rising tone } \\
! \quad & = & \text { a dolling tone } \\
& & - \text { Level low tones are not marked. }
\end{array}
$$


- The tone is only marked on the first part of a diphthong or a triphthong.

- Upper case letters mark an underspecified segment.

\section{Lama Phonology and Noun-Class Morphology}

Lama is a West African language of the Gur family, spoken by some 60,000 people in the northern part of Togo. Lama belongs to the Eastern Grusi language group, together with Kabiye, Lukpa, Delo, Cála, Tem, and Bago [DeCraene 1986].

2.1. Main features in Lama phonology. To understand the discussion that we present in section 3 of this paper, an introduction to the main phonological features of Lama proves relevant at this point. This introduction centers mainly on the consonantal system, the vowel system, the tonology, and the syllable structure.

The consonants. Lama presents 13 consonants and 2 glides in the underlying representation: the stops $/ p, k p, t, c, k /$, the fricatives $/ f, s, h /$, the sonorants $h, r$, $m, n, \tilde{n}, w, y /$.

Note that [-voiced] and [+voiced] are not contrastive in the stops and fricatives of the Lama consonantal system. However, intervocalically, and after nasals the stops $/ \mathrm{p} /, \mathrm{kp} /$, and $/ \mathrm{k} / \mathrm{can}$ be voiced or voiceless depending on the speaker. In other words, the feature [+voiced] is a secondary feature in free variation with the primary feature [-voiced].

Two additional consonants are found at the surface level. These are the velar nasal [ $\mathrm{g}$ ] and the retroflex stop [d]. As will be shown in section 3, these consonants are phonetically derived from other specific underlying segments through phonological processes.

To sum up then, Lama starts from an underlying 15 consonantal system and ends up with 17 consonants at the surface level.

The vowels. The language presents 11 vowels in the underlying representation. In this study, we will use the features [+ATR] and [-ATR] to present the vowel system in Lama and the type of harmony that system governs (section 3.2.2). In (2) we present this ATR vowel system. 


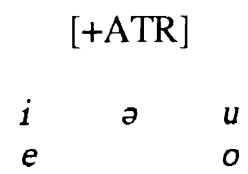

u
$[-\mathrm{ATR}]$

$\begin{array}{lll}i & 3 & t \\ \varepsilon & & \nu\end{array}$

a

Note that, in the underlying representation, the low vowel /a/does not show an ATR contrast as the other vowels do in (2). At the surface level, however, that vowel shows a contrasting [+ATR] $([\Lambda])$ counterpart which fills the gap we note in the underlying representation of the vowel system as illustrated in (2). [+ATR] vowel harmony, as motivated in this study (cf. section 3), therefore, leads from an 11 underlying vowel system to a 12 vowel system at the surface level. We now turn to the tonal system.

The tonal system. Lama has two basic tones, a high tone and a low tone. These tones combine to give two contour tones, a falling tone and a rising tone. The latter is never realized phonetically. It always surfaces as a low tone. But when a low tone monosyllabic word follows a word with a final rising tone, the high part of that contour tone is then felt on that monosyllabic low tone word. This is explained by the general phenomenon of the high tone spread one syllable to the right found in most Gur languages [Kenstowicz et al. 1988]. The falling tone is only realized phonetically on the final syllable of a word (said in isolation). In phrase medial position, the falling tone simplifies to a level high tone; the delinked low part can cause a following high tone to be downstepped in specific environments [Kenstowicz et al. 1988].

Lama starts then with two basic tones which in turn combine to give two additional tones. The overall tone configurations are High, Low, High-Low, and Low-High in the underlying represenation. At the surface level only the first three configurations are allowed. The syllable, to which we now turn, is the tone bearing unit.

The syllable. Four possible combinations of vowels and consonants into monosyllabic words form the basic syllable structure in Lama. Such combinations are shown and illustrated in (3).

(3) Syllable structure in monosyllabic words

$\begin{array}{lll}\mathrm{V} & i & \text { 's/he, it' } \\ \mathrm{VC} & \text { àr } & \text { 'which' } \\ \mathrm{CV} & \text { tá } & \text { 'in' } \\ \mathrm{CVC} & k a 1 & \text { 'read' }\end{array}$


While any consonant can occur in the onset position, only sonorants (except for palatal sonorants $/ \tilde{n} /$ and $/ y /$ ) are allowed in the coda position, where consonant clusters are forbidden. Derived prenasalized stops [mp] and sonorants [ññ], [ñy], [nn] are found in the onset position. In cases where the nasal consonant fails to merge with the following consonant into a complex segment, that nasal consonant becomes syllabic. For instance, when $s_{3}$ 'they $=$ children' and $k a$ 's/he = child' are prenasalized, the nasals in $n s 3$ 'these/those ones = children', and $\eta \mathrm{ka}$ 'this/that one $=$ child' are syllabic and bear a tone of their own. These words are therefore disyllabic words in contrast to $\mathrm{mpa}$ 'these/those ones $=$ men' and $n d 3$ 'this/that one = axe', which are monosyllabic words.

In this section of the paper, we have presented four main points in Lama phonology: we have shown that the language has 15 consonants in the underlying representation; for stops and fricatives, [-voiced] is the main specified feature which does not contrast with the feature [+voiced] found in some environments at the surface level. Two additional consonants $[\eta]$ and $[d]$ are phonetically derived as will be argued for in the next section.

Eleven vowels are found in the underlying representation contrasting in [ATR] values except for the low vowel /a/. That vowel, like all the other [-ATR] vowels, harmonizes in the environments of [+ATR] vowels. ATR vowel harmony is considered in detail in the last section of this paper.

Lama has a two tone register, a high tone and a low tone. These tones combine into contour tones (a falling tone and a rising tone). The rising tone never surfaces whereas the falling tone only surfaces at phrase final position. Contour simplification is followed by tone spread one syllable to the right and downdrift. The syllable is the tone bearing unit.

There are four possible syllable stuctures (cf. (3)). Only sonorants (palatals excluded) can occur in the coda position where consonant clusters (including complex segments) are forbidden.

After this general introduction to the phonology of the language, let us consider the main features of the noun class morphology.

2.2. Noun class morphology. All of the languages in the Gur family share the common characteristic of a noun class system, as exemplified by Lama in the present study. The first comprehensive description of Lama was published in Prost [1964], who provides a six noun class system for the language. His study does not consider the singular and the plural of the same noun as belonging to two different classes. For instance, the elements in (4) from Prost's [1964:10] analysis belong to the same class, i.e. Class 1 . 
(4) Singular

\author{
Plural
}

$\begin{array}{lll}\text { yir } & \text { 'person' } & \text { yira } \\ \text { apal } & \text { 'man' } & \text { apala } \\ \text { yal } & \text { 'woman' } & \text { yala } \\ \text { di } & \text { 'mother' } & \text { dina }\end{array}$

What Prost basically does is to pair up the singular form and the plural form of the same lexical item in one noun class even though they do not govern the same morphology or the same agreement.

The second approach to the noun class system of the language has been proposed by Ourso and Yu [1987]. In their study, they refined Prost's classification by considering singular and plural as additional criteria for the recognition of classes. For them, all the elements in Class 1 will share the same singular properties but not necessarily the same plural characteristics. This implies that while some nouns in Class 1 have their plurals in Class 2, others have theirs in Class 4. This is exemplified in $(5 a, b, c)$ and $(6 a, b)$.

a. Class 1

$\begin{array}{ll}\text { yír } & \dot{i} \\ \text { yà1 } & \dot{i} \\ \text { nâa } & i \\ \text { ñàr } & \dot{i}\end{array}$

Representative

Pronoun
กีกว

กักิว

กักว

กิกั3
Demonstrative Pronoun

b. Class 2

$$
\begin{aligned}
& \text { yír-âa } \\
& \text { yal-âa }
\end{aligned}
$$

wa

wa

mpa

mpa

'persons'

'women'

c. Class 4

$$
\begin{aligned}
& \text { nâa-n } \\
& \text { ñarŝ-n }
\end{aligned}
$$

กิว

กกับ

กีกับ

'cows'

'buffalos'

(6) a. Class 3

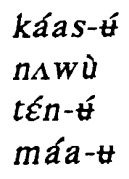

$k *$

$k t$

$k t$

$k t$

'person'

'woman'

'cow'

'buffalo' 
b. Class 4

\begin{tabular}{|c|c|c|c|}
\hline kássồ-n & กิ3 & กีกว & 'crocodiles' \\
\hline$n \Delta w \hat{u}-n$ & กิ3 & กีกิว & ‘bulls’ \\
\hline$t \varepsilon n \hat{3}-n$ & กิ3 & กีกิว & 'skins' \\
\hline mâa-n & กิ3 & กี่ & 'rice' \\
\hline
\end{tabular}

The synthesis of this classification is shown in the tables in (7) and (8), adapted from Ourso and Yu [1987]:

(7) Table l. Noun class system of Lama

\begin{tabular}{|c|c|c|c|c|c|c|}
\hline Class & Number & Corr. Class & Cl. Suff. & Pronoun & Demonst & Refer. \\
\hline 1 & Sing. & 2,4 & $\varnothing$ & $i$ & กิกี3 & \multirow[t]{2}{*}{ Human } \\
\hline 2 & Plur. & 1,3 & $\begin{array}{c}-w a,-a \\
-n a\end{array}$ & wa & $m p a$ & \\
\hline 3 & Sing. & $2,4,9$ & -4 & $k t$ & $\eta k t$ & \multirow[t]{2}{*}{ Animate } \\
\hline 4 & Plur. & 1,3 & $-n$ & $\tilde{n}{ }^{n}$ & กีกั3 & \\
\hline 5 & Sing. & 6 & $\begin{array}{c}-k a,-0 \\
-p e\end{array}$ & ka & pka & \multirow[t]{2}{*}{ Small } \\
\hline 6 & Plur. & 5 & -53 & 53 & $n s 3$ & \\
\hline 7 & Sing. & 8 & $-13 .-d 3$ & 13 & $n d 3$ & \multirow[t]{2}{*}{ Small } \\
\hline 8 & Plur. & 7 & $\begin{array}{c}-y a,-a \\
-i\end{array}$ & $y^{a}$ & $\tilde{n} y a$ & \\
\hline 9 & & 3 & -13 & t3 & $n+3$ & Collect \\
\hline 10 & & & $-m$ & pз & $m p 3$ & Liquid \\
\hline
\end{tabular}

Table 1 is interpreted as follows: in Column 3 (from left), 2, 4 means that all the elements in Class 1 have their plurals either in Class 2 or in Class 4, etc.; Column 4 shows the various class markers which can be suffixed to the noun in the appropriate noun class; Column 5 shows independent pronouns which can be subjects (or objects) of verbs; Column 6 shows the demonstrative pronouns. These elements can also be adjoined to the nominal as demonstrative articles (yalâ 
mpa 'these/those women', mpa 'these/those ones'). When the demonstrative of the noun class 1 acts as an article it loses its prenasalizing element (ññ 'this one' versus yà1 ñз 'this/that woman'). Column 7 (Ref. = Referent) gives a tentative semantic interpretation of the various noun classes.

Table 2 illustrates the noun class suffixes:

(8) Table 2. Noun class suffixes in context

\begin{tabular}{|c|c|c|c|}
\hline Class & Singular & Plural & Gloss \\
\hline $1 / 2$ & 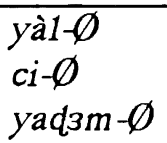 & $\begin{array}{l}\text { yal-âa } \\
\text { ci-ná } \\
\text { yadзm-pa }\end{array}$ & $\begin{array}{l}\text { 'woman' } \\
\text { 'father' } \\
\text { 'cowife' }\end{array}$ \\
\hline $1 / 4$ & $\begin{array}{l}\text { ti-Ø } \\
\text { tâa-Ø }\end{array}$ & $\begin{array}{l}\text { tîi-n } \\
\text { tâa-n }\end{array}$ & $\begin{array}{l}\text { 'elephant' } \\
\text { 'antelope' }\end{array}$ \\
\hline $3 / 2$ & $\begin{array}{l}t \hat{t}-u \\
w S m 1-\hat{t}\end{array}$ & \begin{tabular}{|l|} 
tí-wâa \\
wóm1-âa
\end{tabular} & $\begin{array}{l}\text { 'fortune-teller' } \\
\text { 'leper' }\end{array}$ \\
\hline $3 / 4$ & $\begin{array}{l}\text { tén-ष́t } \\
\text { káas-t }\end{array}$ & $\begin{array}{l}\text { tén } \hat{3}-n \\
\text { káas }-n\end{array}$ & $\begin{array}{l}\text { 'skin' } \\
\text { ‘crocodile' }\end{array}$ \\
\hline $3 / 9$ & $\begin{array}{l}\text { háar-ú } \\
\text { hér-ú }\end{array}$ & 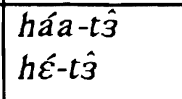 & $\begin{array}{l}\text { 'leaf (bunch of)' } \\
\text { 'flower (bunch of)' }\end{array}$ \\
\hline $5 / 6$ & $\begin{array}{l}\text { ará-kâa } \\
a m-\hat{\jmath}\end{array}$ & 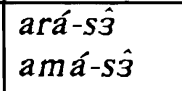 & $\begin{array}{l}\text { 'trunk' } \\
\text { 'lizard' }\end{array}$ \\
\hline $7 / 8$ & 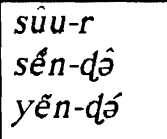 & $\begin{array}{l}\text { sú-yá } \\
\text { sén-á } \\
\text { yem-í }\end{array}$ & $\begin{array}{l}\text { 'back' } \\
\text { 'bean' } \\
\text { 'hippopotamus' }\end{array}$ \\
\hline 9 & & & $\begin{array}{l}\text { 'friendship' } \\
\text { 'fear' } \\
\text { 'wealth' }\end{array}$ \\
\hline 10 & & & $\begin{array}{l}\text { 'water' } \\
\text { 'blood' } \\
\text { 'wind' }\end{array}$ \\
\hline
\end{tabular}

Although Ourso and Yu's classification presents more details with more clarity than that of Prost [1964], it also shows certain inadequacies in the semantic interpretation of the noun classes. For instance, the interpretation of the noun classes $1 / 2$ as "human" can be misleading since the lexical elements in those classes can

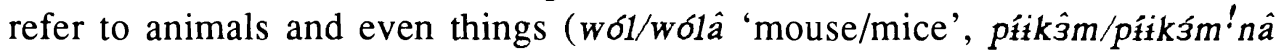


'flute/flutes'). The same heterogeneity also holds for the other noun classes. This implies that semantic interpretation as a criterion of classification is not satisfactory, and it therefore needs further investigation.

From these tables, the following generalizations can be made about the noun class system of Lama: (1) noun class 1 does not have a lexical suffix; (2) apart from noun class 1 there is a structural relation between the noun class pronouns and the corresponding demonstratives; (3) some noun classes have the class pronoun as their suffix.

After this introduction to the noun-class system of Lama, let us consider the phonological processes involved in affixation.

\section{Phonological Processes}

As already mentioned at the beginning of this paper, our discussion will center on three phonological points, namely, assimilation and related processes, vowel truncation, and vowel harmony.

3.1. Assimilation processes. Within the same noun class and across the different noun classes two assimilatory processes take place: nasal assimilation and sonorant hardening.

3.1.1. Nasal assimilation. Prenasalization of the demonstrative pronouns is a common characteristic of all the noun classes. Consider, for instance, the following data:

(9) Table 3. Interaction between noun class elements

\begin{tabular}{|c|c|c|c|c|c|}
\hline Cl. & Numb. & Noun & Noun + Demons. & Pronoun & Demons. \\
\hline 1 & Sing. & $\begin{array}{l}\text { yà1 } \\
\text { 'woman' }\end{array}$ & yà1 n̂̉ & $i$ & กิกีว \\
\hline 2 & Plur. & yalâa & yalámpa & wa & $m p a$ \\
\hline 3 & Sing. & $\begin{array}{l}\text { káasút } \\
\text { 'crocodile' }\end{array}$ & káasú ṕk甘 & $k t$ & $\eta \mathrm{kt}$ \\
\hline 4 & Plur. & káaş̂n & káaş́n ñก̃a & กิ3 & กีก๊ว \\
\hline 5 & Sing. & $\begin{array}{l}\text { yó } \\
\text { "child" }\end{array}$ & yó ǵka & $k a$ & $\eta k a$ \\
\hline 6 & Plur. & Wísầ & wísá ns3 & s3 & $n s 3$ \\
\hline
\end{tabular}




\begin{tabular}{|l|l|l|l|l|l|}
\hline 7 & Sing. & $\begin{array}{l}\text { sûur } \\
\text { 'back' }\end{array}$ & súur nd3 & r3 & nd3 \\
\hline 8 & Plur. & súyá & súyá ñyá & ya & ñya \\
\hline 9 & & $\begin{array}{l}\text { wurtâ } \\
\text { 'leadership' }\end{array}$ & wurtá nt3 & t3 & nt3 \\
\hline 10 & & $\begin{array}{l}\text { lềm } \\
\text { 'water' }\end{array}$ & lém mp3 & p3 & mp3 \\
\hline
\end{tabular}

If we consider the demonstrative pronouns, we observe the following facts: first, a nasal consonant is observed at the beginning of each demonstrative. Second, each observed nasal is homorganic to the following consonant. And third, comparing the demonstrative pronouns with the noun class subject/object pronouns, only the nasal prefix in the demonstratives makes the difference between them.

From these facts, we can therefore deduce that there is an assimilation process. An attractive way to account for this process is to adopt the underspecification framework and posit an archiphoneme, $/ N /$, underlyingly specified for the feature [+nasal] only. In this framework, then, the other features (labial, alveolar, velar, palatal, etc.) will be filled in for the nasal sound in place of articulation at a later stage of the derivation.

Following Clements [1985], we motivate three tiers - a manner tier, a supralaryngeal tier, and a place tier-to account for nasal assimilation in Lama. The features of the homorganic sound on the place tier spread backward on to the nasal node on the supralaryngeal tier. The nasal assimilation rule as described above is given in (10).

(10) Nasal assimilation

Manner Tier

Supralaryngeal Tier

Place Tier

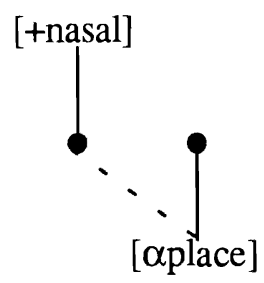

This rule will therefore derive the appropriate nasal with respect to place of articulation as specified by $\alpha$.

Turning back to the data in (9) again, particularly to the columns labelled "Pronoun" and "Demonstrative", note that after the N prefixation the initial con- 
sonants of Class 2 pronoun wa 'they/them' and of Class 7 pronoun $r 3$ 's/he, her, his, it, its' undergo a structural change. Both sonorants undergo a hardening process to the corresponding obstruent, namely $/ w /$ to $[p]$ and $/ r /$ to $[d]$ by losing their feature [+continuant]. We consider the hardening processes in the next two sub-sections.

3.1.2. Labial assimilation. If we posit $/ p /$ in the $m p a \sim w a$ alternation as the underlying sound, we can formulate a rule which will take $/ p /$ to $[w]$, for instance, at word initial position. There is a historical motivation for this approach. For instance, in his reconstruction of the consonants of the ProtoEastern Grusi, Manessy [1969] shows that there are three different proto-bilabial stops $\left({ }^{*} \mathrm{~B} 1,{ }^{*} \mathrm{~B} 2,{ }^{*} \mathrm{~B} 3\right)$ common to all of the nineteen languages he studies. The three proto-sounds are differently realized in each language. In relation to ${ }^{*} \mathrm{~B} 1$, which is of immediate interest to our discussion, Manessy [1969:28] shows that this sound is synchronically realized in seventeen langauges as $/ b /$, in the eighteenth language, Kabiye, it is realized as $p / b$, whereas Lama is the only language in which it is realized as $/ w /$ at initial position. To explain this exception, Manessy argues that Lama must have introduced a diachronic rule to reduce $* \mathrm{~B} 1$ to $/ \mathrm{w} /$ as observed in its class pronominal system.

Although this evidence supports the rule which would take $/ p /$ to $/ w /$ at word initial position, resulting in the structural change as observed in the pronominal system of noun class 2 , such an analysis is restricted in scope with respect to certain synchronic facts. First, recall that there is no $p / b$ contrast. Second, both $/ p /$ and $/ w /$ occur in word initial position as well as in word medial position, as shown in $(11 \mathrm{a}, \mathrm{b})$ :
$\begin{array}{ll}\text { a. } & \text { wa 'they' } \\ \text { ii. wads 'a walk' }\end{array}$
iii. $w \hat{\varepsilon} \varepsilon r$ 'a stone'
iv. pâ (10) 'any (where)'
v. pelt̀ a species of fish
vi. pú 'a barn/silo'
b. i. awôr 'a place/position'
ii. səwìir 'peanut (a grain of)'
iii. apá 'mom'
iv. apker proper name

This implies that both sounds exist underlyingly. Third, the $p \sim w$ alternations can also be found elsewhere in the language. Consider, for instance, the data in (12 a-d): 
(12)
a. hóm
'to pull'
rám
'to bite'
kám
'to come'
b. mз hоm-pá 'I pulled'
mз rзm-pá 'I bit'
mз kam-pá 'I came'
c. ná-u
'to see'
$c o ́-u$
'to listen'
$n \dot{t}-\mathbf{t}$
'to carry on the lap'
d. mз na-wá 'I saw'
mз co-wâ 'I listened'
mз n甘-wá 'I carried on my lap'

In (12a) we have one category of verbs whose base forms are $\mathrm{CV} m$, whereas in (12c) we have another category of verbs with a CV root. The $(-u)$ observed in the latter case is what we might call an infinitive marker. Except in $\mathrm{CV}_{m}$ and $\mathrm{CV} p$ categories of verbs, the infinitive marker attaches to all the other roots in the infintive forms. That is, there are CV-u as well as CVC-u (kát-tr 'to meet', kpác- $\mathbf{\sharp}$ 'to lead' etc.) infinitives.

In $(12 b)$ and (12d) the perfective marker attaches to the verb root, where we observe the alternation between $p$ and $w$. If we assume that $/ p /$ underlies the phonetic $[w]$, we can formulate a rule as in (13).

$$
\mathrm{p} \rightarrow \mathrm{w} /\left\{\begin{array}{c}
\mathrm{V} \\
\#
\end{array}\right\}
$$

But rule (13), which says that $/ p$ / becomes [w] after a vowel or at word initial position, does not account for the lexical elements in (11a, iv-vi) and (11b, iii-iv). Under this analysis, such cases as the preceding ones can only be considered as an exception to rule (13). This approach predicts that there is no structural relation between the noun class pronoun and the noun class demonstrative. In other words, the subject/object pronoun is not the input to the demonstrative formation. Furthermore, this analysis excludes the possibility of $/ \mathrm{w} /$ assimilation to the preceding homorganic sound such as the labial nasal in feature [coronal]. It also predicts that two homorganic sounds such as $/ \mathrm{m} /$ and $/ \mathrm{w} /$ cannot merge into a single complex sound like a prenasalized obstruent $[\mathrm{mp}]$. 
The other alternative is to posit $/ w /$ as the underlying segment and derive $[p]$ from it through assimilation processes. We adopt this analysis for the following reason: first, we have established both $/ p /$ and $/ w /$ in the lexicon; second, the environment established for the derivation of $[w]$ from $/ p /$ does not account for all the data; third, $/ w /$ to $[p]$ derivation as an assimilatory process can account for the data in a simpler way.

The labial assimilation rule can therefore be formulated as in (14).

\section{(14) w Strengthening}

a. Manner Tier

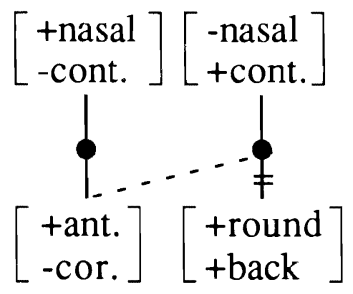

b. Manner Tier

[-cont.] [+cont.]

Supralaryngeal Tier

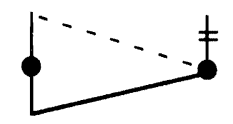

Place Tier

$$
\left[\begin{array}{l}
\text { tant. } \\
\text {-cor. }
\end{array}\right]
$$

Note that rule (14) is a partial elaboration on rule (10) in terms of feature specification. In (14a), the first step consists in spreading the features of the nasal as specified on the place tier onto the node of the bilabial continuant on the supralaryngeal tier as shown by the broken line. The second step consists in delinking the previous place node as illustrated by the double slash. In this specific case, the features of $w$ must be affected on the manner tier as well. The feature [+continuant] must be delinked from that tier as shown by the process in (14b).

We consider this type of assimilation as a total assimilation in that the resulting sound [mp] cannot be dissociated into individual segments on the syllable template. That is, unlike partial assimilation of the nasal where the nasal sound can either form a syllable by itself ( $\eta \$ k a$ 'this/that one') or be attracted to the pre-

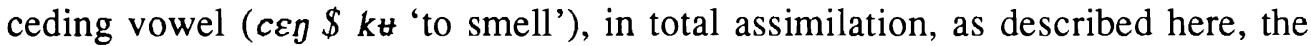
nasal and the following stop form a single complex segment which can only be in the onset position in the syllable structure. For instance mpa 'these/those ones' is 
a monosyllabic word whereas ${ }^{*} m \$ p a$ as a disyllabic word is ungrammatical as indicated by the star. The features of this complex segment are given in (15).

(15) Features of the complex st;ment

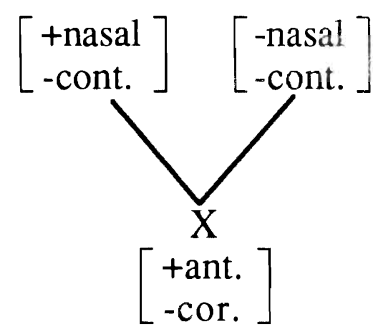

An immedicate issue is what happens to the slot of the nasal in the coda position when that nasal becomes part of a complex segment through total assimilation as presented above. Prenasalization affects the quality of the vowel with which the nasal forms the rime in the input syllable. That vowel becomes nasalized as shown in (16).
a. hóm 'pull'
móm 'hit'
róm 'bite'
b. \#hom-wa\# $\rightarrow$ c. hõmpá 'puli-past'
\#məm-wa\# $\rightarrow \quad$ mómpá 'hit-past'
\#rзm-wa\# $\rightarrow \quad$ rз̃mpá 'bite-past'

In (16c), we have the $w$-strengthening process followed by prenasalization. the nasal which was initially in the coda position now becomes part of the onset positon. As a result, note that the vowel of the root in (16c) becomes nasalized. If we argue that the template of the input syllable must not be affected in the output in terms of prosodic slots, we can therefore claim that vowel nasalization as observed in (16c) is a compensatory process. The motivation for this process would then be the preservation of the input syllable structure. If our arguments are correct, then, the vowel nasalization rule, fed by the process of complex segment formation, can be formulated as in (17). 
(17) Vowel nasalization

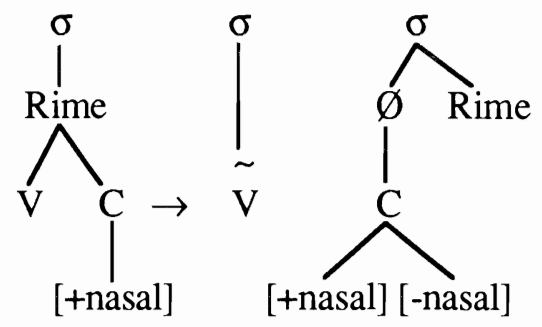

In (18) we illustrate the rules developed so far.

(18)

\begin{tabular}{|c|c|c|c|c|}
\hline$\# N w a \#$ & $\# n a+w a \#$ & \#wa\# & $\#$ Hom+wa\# & \\
\hline \#mwa\# & ---- & -..- & ---- & rule 10 \\
\hline$\widehat{m p} a$ & --- & ---- & hompa & rule $14-15$ \\
\hline ---- & ---- & ---- & hõmpa & rule 17 \\
\hline$\widehat{m p} a$ & nawá & wa & hõmpá & phon.real. \\
\hline 'these ones' & 'saw' & 'they' & 'pulled' & \\
\hline
\end{tabular}

3.1.3. The $r \sim \boldsymbol{q}$ alternation. In the data presented in (9), we observed the alternation between the retroflex sonorant $r$ and the retroflex stop $q$. This alternation is productive, as is further illustrated in (19a and c).
Sg., Class 7
pl., Class 8

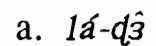

$1 \hat{s}-d \hat{s}$

'axe'

'scab'

b. 1ál-á

$m \hat{\xi}-d \hat{s}$

'millet'

13́1-á

$m\}-d \hat{3}$

'story'

m 3́1-á

sên-dî

'bean'

m3́r-á

mån-d̂े

'okra'

sén-á

yẽ̃n-dŕ

'hippopotamus'

mán-á

yem- $\hat{\mathbf{1}}$

c. mîî-r
$k \hat{o} \supset-r$
$s \hat{u} u-r$
$s \grave{\varepsilon}-r$

'nose'

d. má-yá

'medicine'

kś-yá

'back'

sú-yá

'field mouse'

$s \varepsilon-y a ́$

Before we discuss the data, let me recall some morphological and phonological facts about noun classes $7 / 8$. The class marker in singular (Class 7 ) is the $-r /-d 3$ 
observed in (19a and c), whereas the plural markers in the corresponding class 8 are $-y A,-A,-I$ exemplified in $(19 \mathrm{~b}$ and $\mathrm{d})$.

Comparing the first four lexical elements in (19a) with their corresponding plural forms in (19b), we note :'at the stems in (19b) show the consonants $(1, r)$ which are absent in (19a). Note also that in the remaining lexical elements in $(19 \mathrm{a}$ and $\mathrm{b})$ the nasal consonants the nasal sound of the last word.

Taking the roots in (19b) as the uncerlying representation of those in (19a), we can argue that when the marker of the noun class 7 is suffixed to the root it triggers a phonological process which affects the root final sound in that class. This hypothesis is supported by the data in $(19 \mathrm{c})$. If we agree that the roots in (19b and d) are the ones that show the underlying forms of those in (19a and c), we can therefore claim that the long vowels oberved in (19c) arise as a result of the same suffixation in noun class 7 . Assuming that our hypothesis is correct, two main points call for attention with respect to the data in (19a and c). First, the $r / d$ alternation must be explained; second, what happens to the root final sounds after suffixation has to be accounted for.

Assuming that $r$ and $q$ are both underlying sounds with $q$ functioning with the sonorants $(1, r, m, n)$ instead of functioning with the stop sounds as we claimed so far, the following predictions fall out from this assumption:

(1) $-r_{3}$ and $-d 3$ are then both noun class 7 suffixes in complementary distribution: $-d 3$ occurs with final consonant roots while $-r 3$ can only occur with vowel final roots.

(2) The sonorant $q$ causes the dissimilaton of the root final consonants, nasals excluded. The suffix $-r 3$ loses its schwa after a vowel, triggering a compensatory lengthening in the root final vowel. This would explain the various alternations in the data in (19).

(3) Under this assumption, there is no allophonic relation between the sounds $r$ and $q$.

Although this approach seems plausible and accounts for the phonological variation in the sample data presented above, it proves contradictory with the phonological and morphological facts.

Phonetically, $r$ and $q$ do not contrast in word initial position or in word final position. In the syllable coda position, all the sonorants occur except for $\tilde{n}$ and $y$, but $q$, stops, and fricatives do not occur in that position either. If $q$ functions with sonorants, it can be argued that it is part of the sonorants excluded in the syllable coda position. However, morphological evidence against this argument will be 
presented in due course. Meanwhile, note that where $r$ and $q$ seem to contrast is in the medical position as illustrated by the data in (20a and b).

(20)
a. wúrô 'chief'
fíró 'gourd'
máart́ 'mark'
sartî 'beauty'
sárka 'prison'
b. sads 'frog'

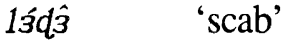
wód $\hat{\theta} \quad$ a variety of tree
sзdз 'a corpse'
mз́d̂̉ 'millet'

Recalling the arguments that the roots in (19a) are in fact final consonant roots (as evidenced by the corresponding roots in (19b)), where the occurrence of $r$ is excluded, it becomes clear that this contrast between $r$ and $q$ in that position is misleading.

Morphological evidence other than the $r / q$ facts in noun class 7 shows that there is an allophonic relation between these two sounds. Consider for instance the data in (21).

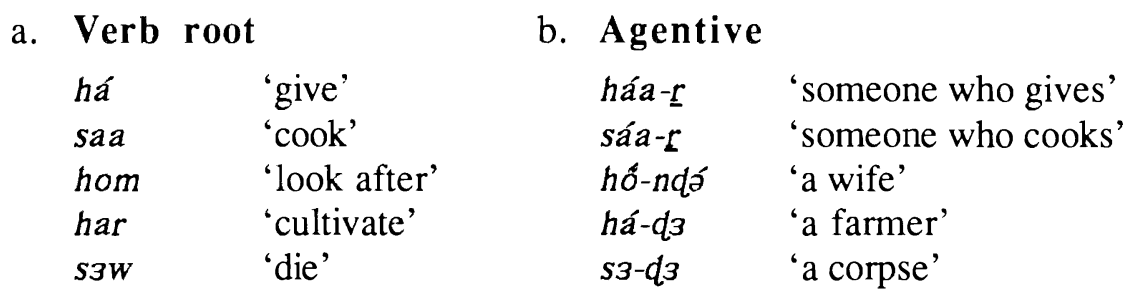

All the agentives in (21b) belong to noun class 1 which does not have an overt class suffix. The agentive formation suffixes the $r / d$, observed here, to the verb roots. Note the striking similarities between the structural alternations in the verb roots here and those in the noun roots in noun class 7 in (19). This further evidence shows that the $r / d$ alternation in the noun class 7 is not an isolated fact. Moreover, this evidence establishes the fact that $r$ and $q$ are allophones of the same underlying phoneme.

If we argue that $/ r /$ underlies both the phonetic retroflex $[r]$ as well as the retroflex $[q]$, we can motivate a sonorant hardening process such as the one already argued for in the case of the $w / p$ alternation; the facts observed here would then naturally fall out from the approach taken to account for the $w / p$ and related 
variations. Assuming that our hypothesis is correct, the rule turning the retroflex sonorant $/ r$ /into the retroflex stop [d] can therefore be formulated as in (22).

(22) $r$-Hardening

$$
\left[\begin{array}{l}
\text {-ant } \\
\text { +cor. } \\
\text { +voice }
\end{array}\right] \rightarrow\left[\begin{array}{l}
\text { tant. } \\
\text {-cor. } \\
\text { +voice }
\end{array}\right] / \mathrm{C}
$$

The input to rule (22) will be the underlying representation of (19a) presented in (23a) for convenience. Applying rule (22) will give the initial result in (23b).

\begin{tabular}{|c|c|c|c|}
\hline a. \#1a1-rß\# & $\rightarrow$ & b. 1 ald 3 & 'axe' \\
\hline \#121-r3 & $\rightarrow$ & $101 d a$ & 'root' \\
\hline \#m 31-rз\# & $\rightarrow$ & $m 31 d 3$ & 'millet' \\
\hline$\#$ m зr-rз\# & $\rightarrow$ & $m 3 r d 3$ & 'story' \\
\hline \#sen-rß\# & $\rightarrow$ & sendo & 'bean' \\
\hline \#man-rз\# & $\rightarrow$ & $\operatorname{mand} 3$ & 'okra' \\
\hline \#yem-rз\# & $\rightarrow$ & yemdo & 'hippo' \\
\hline
\end{tabular}

A cluster simplification rule will delete the root final consonant except for nasals which, as already seen, assimilate to the following consonant and serve as prenasalization to some stops. Before we motivate the cluster simplification rule, we need more evidence. Consider the following data.
a. sg., Class 5
má1-ś
'millet'
b. pl., Class 6
ñá1-ó
'plate'
$m \hat{3}-s \hat{3}$
kpár-s
'bracelet'
ñá-s
$k p a ́-s \hat{3}$

In (24a) the noun class 5 marker -0 is suffixed to the noun roots. The examples in (24b) show the same noun roots with the noun class 6 suffix -s3. Here, we observe the absence of the root final consonant from (24a) to (24b). This is the same phenomenon as in (19). This evidence enables us to formulate the cluster simplification rule as in (25).

(25) Cluster simplification

$$
\mathrm{C} \rightarrow \varnothing / \_\mathrm{C}
$$

[-nasal] 
The application of this rule to (23b) and to the underlying representation of (24b) will yield the results in (19a) and (24b) respectively. Note, however, that the cluster simplification rule fails to apply to the data in (20a). At this stage of our investigation, we cannot offer an accurate explanation for this exception. One of the possible explanations has been offered in Ourso [1988] within the framework of lexical phonology.

Recall that after $w$-strengthening, the resulting stop and the nasal sound merged into a complex segment triggering nasalization in the preceding vowel. The same process applies here in the same environment after $r$-hardening. Note, for instance, the assimilation of the bilabial nasal (yemd $\rightarrow$ yẽ $\$$ nqo 'hippo.') to place of articulation to the retroflex $q$ followed by vowel nasalization. This, then, is further evidence that the retroflex $q$ does not function with the sonorants but with the stops.

On the evidence that $r$ and $w$ are both sonorants undergoing hardening and complex segment formation, it is more attractive to collapse rule (14) and rule (22) into a single rule to account for this process of hardening. In (26), we present the collapsed rule.

(26) Sonorant Hardening

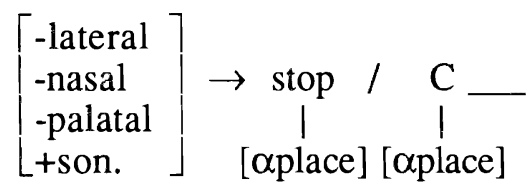

Rule (26) claims that the derived stop is determined by the place of articulation of the consonant that causes the input sonorant to become a stop.

This approach leads us to formalize the prenalization rule in the target stops as follows:

(27) Prenasalization

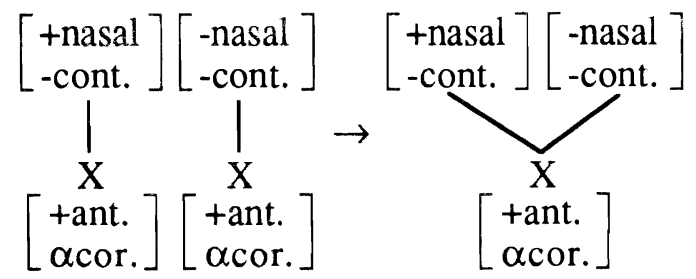

So far, we have explained the $r / q$ alternation which triggers the deletion of the root final consonants except for nasals. The alternation between schwa and zero 
observed in (19a) to (19c) and the vowel lengthening in (19c) need to be considered.

If we consider Table 1 in (7), we note that in most cases the class pronoun is also the class suffix. Assuming that the overall structure of the pronouns is CV and that that structure is kept in the pronominal suffix, the following interpretation can explain the facts presented by the data. After the sonorant $/ r /$ becomes a stop, the schwa is kept for the general reason that obstruents do not occur in the coda position in this language. Following this line of argument, we can claim that after suffixaton of $-r 3$ to the vowel final roots the sonorant is attracted to the syllable coda position causing a schwa syncope. The motivation for this claim comes from the striking relation between the noun class 4 pronoun ñз 'they/them' and the corresponding class suffix $-n(\operatorname{cf}(5)$ in section 1$)$ ). If the claim that the class pronouns $r 3$ and ñ 3 are also the class suffixes is correct, we can motivate the schwa syncope rule as proposed in (28).

\section{(28) Schwa syncope}

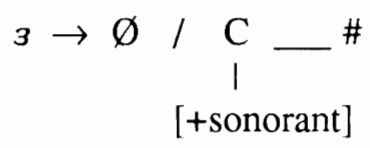

Rule (28) says to delete the schwa after a sonorant at word final position. This rule must be ordered after the hardening rule to avoid wrong results in the $/ r /$ to [d] derivation.

As already argued for in the case of prenasalization, the vowel lengthening observed in (19c), as well as in similar environments in the noun class 4 , can be explained as a compensatory lengthening. The compensatory lengthening is motivated by the integrity of the input slots on the prosodic tier in the syllable template; if the number of the output slots must be the same as that of the input slots, then vowel nasalization and vowel lengthening are considered as the same process of compensation; in this view, then, the vowel lengthening rule, fed by rule (28), can be formulated as in (29), where J shows the root final position.

\section{(29) Vowel lengthening}<smiles>[X][V]C([X])([X])[Al]CC(C)O</smiles>

Because palatal sonorants do not occur in the syllable coda positon, the loss of the schwa in the suffix -ñ triggers a depalatalization rule proposed in (30). 


\section{(30) Depalatalization}

$$
\left[\begin{array}{l}
\text { +nasal } \\
\text { +palatal } \\
\text { +coronal }
\end{array}\right] \rightarrow\left[\begin{array}{l}
\text { +nasal } \\
\text {-palatal } \\
\text { +coronal }
\end{array}\right] / \mathrm{V}
$$

The rules formulated to account for the processes discussed in this section are illustrated in (31).

(31)

\begin{tabular}{|c|c|c|c|c|c|}
\hline $\begin{array}{c}\text { \#yem-rз\# } \\
\text { yemdз }\end{array}$ & $\begin{array}{c}\text { \#hom-wa\# } \\
\text { hompa }\end{array}$ & $\#$ \#s-rß\# & \#sc-ya\# & $\# t \dot{i}-\tilde{n} 3$ & Hardening \\
\hline yend 3 & --- & ---- & ---- & --- & Nasal ass. \\
\hline yends & hompa & ---- & ---- & ---- & Prenasal. \\
\hline yễnd3 & hómpa & ---- & ---- & ---- & Vowel nasal. \\
\hline -..- & --- & $s \varepsilon r$ & ---- & $\operatorname{tiñ}$ & Schwa sync. \\
\hline--- & --- & $s \varepsilon \varepsilon r$ & $-\cdots$ & tiiñ & Vowel length. \\
\hline ---- & --- & ---- & ---- & tiin & Depalatal. \\
\hline yẽndś & hõmpá & sદેعr & seyá & tiin & Phonetic rep. \\
\hline 'hippo.' & 'pulled' & 'mouse' & 'mice' & 'bees' & \\
\hline
\end{tabular}

So far we have discussed and shown the following points:

(1) In the pronominal system of Lama, the demonstrative pronominals are obtained by prefixing a nasal consonant to the subject/object pronouns of the same noun class. The nasal prefix is not specified for place of articulation in the underlying representation. The features for place are acquired through assimilation to the homorganic consonant.

(2) The sonorants $/ r, w /$ become stops in the appropriate environments. Both $[d]$ and $[p]$ attract the preceding nasal with which they form complex segments. This process triggers nasalization in the preceding vowel. A similar type of compensation is observed when the suffixal sonorant loses its schwa. The root final vowel is lengthened. As a result of schwa syncope, the suffix -ñz undergoes depalatalization. The hardening of the retroflex sonorant affects the root final consonant which triggered the hardening process in the first place. That consonant dissimilates in the environment of the derived retroflex stop [d].

An overall picture of these phonological processes in the noun class system is that some affixal initial sounds and those of some roots affect one another when they come into contact. Vowel initial suffixes also affect the root final vowels in 
the process of noun class formation. The last section of this paper centers on this problem.

3.2. Vowel Truncation and Vowel Harmony. Noun class suffixation offers the most adequate starting point for the study of vowel truncation and vowel harmony in Lama. Let us consider each process.

3.2.1. Vowel Truncation. Among the suffixes of the noun class 5 (cf. (6)) - $O$ and $-k A$ present interesting phonological problems. The suffix $-k A$ will be duscussed later on in this section. Phonetically $-O$ is realized as $[0 / 0]$. This is shown in (32).

Class 5

a. $1 \grave{0}$

Aso

Ahúló

fíró

b. acs

$\operatorname{am\hat {\jmath }}$

กิ5

só 'partridge'

'rabbit'

'branch'

'small gourd'

'fly'

'lizard'

'hair'

'pepper'
Class 6

$a^{\prime}$. lesô

$\Lambda$ sésâ

shưlísâ

fírísâ

b'. acEs $\hat{3}$

amáŝ̉

กี้ $S \hat{3}$

Sîs $3 \hat{~}$

The data in $(32 \mathrm{a}, \mathrm{b})$ can be considered as consisting of the noun root and the noun class marker. In other words, it can be argued that the root just has a final consonant underlyingly. The $\mathrm{o} / \mathrm{s}$ alternation can be accounted for by vowel harmony as proposed in the next part of this section. Note, however, the structural variation of the lexical elements in the corresponding noun class 6 (the plural of class 5).

If we maintain that the noun roots in (32) have just a final consonant underlyingly, we then assume that the class 6 marker is not simply -53 , but it is preceded by a vowel. As can be seen from (32a', b'), that vowel cannot be predicted.

This interpretaton of the data is misleading in that it misses the generalization in recognizing -sз as being simple in structure and the only suffix in noun class 6 . Further evidence should decide on the issue. Let us first consider the plural of other nouns in Class 5.

(33)

\section{Class 5}
a. $w 6$
'river'
ho
'pregnancy'
a'. wó-sâ
hó-sâ 


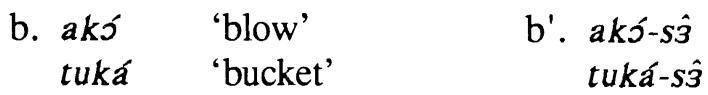

In $\left(33 a^{\prime} \& b^{\prime}\right)$, there is no change in the shape of the root vowel in noun class 6. Although the data in (33) constitute the only cases in which the shape of the vowel in the singular does not change in the plural, they constitute evidence that those vowels observed in class 6 before the affix -53 are undoubtedly root vowels which undergo phonological changes in the process of suffixation in class 5 . Moreover, the pronoun $k A$ 's/he, it' of the noun class 5 is found in certain noun stems and drops in the plural form (class 6). Here again, we observe no vowel change in the root in class 6 . The data in (34) illustrate this case.

Class 5

a.

$\begin{array}{ll}\text { ará-kâ } & \text { 'wooden trunk' } \\ k a t \hat{\varepsilon}-k \hat{a} & \text { 'scarf' } \\ \Delta n 1 \varepsilon-k \Lambda & \text { 'castanets' } \\ \Delta t a ́-k \hat{\Lambda} & \text { 'plain mouse' } \\ \text { afa-ká } & \text { 'quiver' } \\ \text { ráa-ká } & \text { 'firewood' }\end{array}$

\section{Class 6}

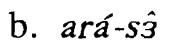

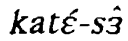

$$
\begin{aligned}
& \text { Anlर्ष-sâ } \\
& \text { Ató-sâ }
\end{aligned}
$$

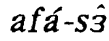

$$
\begin{aligned}
& \text { ráa-ş̂ }
\end{aligned}
$$

Having shown that the vowels observed in (32) are, in fact, root vowels, let us now consider how to account for their absence or their change in the data presented above.

Two possible alternatives can account for this phenomenon. First, we can argue that the root vowel and the suffixal vowel coalesce to give either [o] or [0] depending on the features which merge. This would imply that the suffixal vowel is not necessarily a mid-back vowel to start with. This analysis would deny the existence of $-O$ as a noun class suffix whereas there is evidence that this suffix is one of the noun class 5 markers. In the agreement system of the noun class 5 , it is the suffix $-O$ which is found on the adjective modifying the nominal as exemplified in (35).

(35) a. Class 1 yà1-Ø ḉś́m-Ø 'fair-skinned woman'

b. Class 3

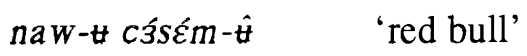




\section{c. Class 5}

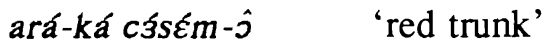

$$
\begin{aligned}
& \text { fir }-\delta \text { çss } \varepsilon m-\hat{\jmath} \text { 'red gourd' }
\end{aligned}
$$

In (43c), note that although the noun class suffixes can be different depending on the noun root, the agreement suffix is the same on the adjective modifying those nominals. This evidence establishes $-O$ as one of the noun class 5 markers.

The second alternative is to motivate a vowel truncation process which deletes root final vowels in front of the suffixal vowel. This approach is more attractive since it follows from the general behavior of root final sounds and initial suffix sounds already discussed in the preceding section. We therefore adopt this alternative and we propose the vowel truncation rule in (36).

\section{Vowel Truncation}

$$
\mathrm{V} \rightarrow \varnothing / \ldots \mathrm{V}
$$

This rule will apply to give the results in (32a \& b). The illustrative process is given in (37) (ignoring vowel harmony rules for clarity).

\begin{tabular}{|c|c|c|c|c|}
\hline $\begin{array}{c}\# 1 e-s o \# \\
-\cdots-.\end{array}$ & $\begin{array}{l}\# 1 e-O \# \\
10\end{array}$ & $\begin{array}{c}\# a c \varepsilon-O \# \\
\text { aco }\end{array}$ & $\begin{array}{c}\text { \#ama-O\# } \\
\text { amo }\end{array}$ & rule (43) \\
\hline lesô & $10 ̀$ & $a c 0$ & $a m \hat{\jmath}$ & phonetic rep. \\
\hline 'partridges' & 'partridge' & 'fly' & 'lizard' & \\
\hline
\end{tabular}

The process of affixation triggers ATR vowel harmony which we would like to consider in the final part of this paper.

3.2.2. Vowel Harmony. The interaction between the roots and the affixes has been differently approached in the literature of phonology. In relation to vowel harmony with respect to root vowels and affix vowels, Clements [1981] and Pulleyblank [1986], among others, both argue that the vowels of the affixes are unspecified for [ATR]. They are governed by the root and therefore harmonize according to "the principle of root control" [Clements 1981:146]. We are taking here this approach to account for vowel harmony in (the noun class system of) Lama.

Before we discuss the harmony processes, we illustrate the ATR vowel system introduced in the second part of the paper. For convenience the two sets are repeated in (38) and illustrated in (39). 
(38) a. [+ATR] vowels

$\begin{array}{llll}\text { high } & i & \partial & u \\ \operatorname{mid} & e & & o\end{array}$

(39)

$\begin{array}{llll}r i & \text { 'mother' } & \text { su! } & \text { 'plant!' } \\ r i & \text { 'python' } & \text { 'take!' } \\ s e ́ ! & \text { 'run!' } & c o ! & \text { 'listen!' } \\ s \varepsilon ! & \text { 'plant!' } & c o ! & \text { 'sit down!' } \\ 101 ! & \text { 'disappear!' } & & \\ 131 ! & \text { 'give birth!' } & \text { wal! 'go!' }\end{array}$

b. [-ATR] vowels

$\begin{array}{llll}\operatorname{high} & i & 3 & \forall \\ \operatorname{mid} & \varepsilon & & 0\end{array}$

low

a

The low vowel /a/ does not have an underlying [+ATR] counterpart. As the data in (39) show, all the vowels contrast minimally in terms of [ATR] in CV words. Such a contrast does not exist in the vowel /a/. However, there is an [+ATR] low vowel $[\Lambda]$ found only in the environment of other [+ATR] vowels. This is illustrated in (40).

$\begin{array}{ll}\text { (40) }[s \Lambda u] & \text { 'a wealthy person' } \\ {[\Lambda s o]} & \text { 'a rabbit' } \\ {[\Lambda \text { selu }]} & \text { 'a catfish' }\end{array}$

The contrast between [+ATR] and [-ATR] low vowel at the surface level is evidence that Lama has a ATR vowel harmony. To account for this type of harmony, we propose the stipulations in (41).

(41) Stipulations for ATR harmony

i. Affixes are not specified for ATR. They obey the "principle of root control", as discussed in Clements [1981].

ii. Some root vowels are specified for [+ATR] underlyingly.

iii. [-ATR] is assigned to vowels not specified underlyingly. 
iv. Once [ATR] is assigned, it associates to the leftmost vowel in the word and spreads rightwards onto the other vowels.

How these stipulations apply in the process of vowel harmony is illustrated in (42).
a. $\operatorname{fir} A-O$
b. hAr-U

In (42), the capital letters refer to vowels unspecified for [ATR]. Vowel truncation applies in (42a) before (41). Thus, (42a) is realized as 'firO'. Stipulation (41ii) then applies to (42a) whereas (41iii) applies to (42b). This is shown in $(43 a, b)$.

\section{ATR assignment}
$+\mathrm{A}$
$-\mathrm{A}$
a. $\quad$ firO
b. $h A r U$

By the stipulation (41iv), [ATR] associates to the leftmost vowel and spreads to the vowels on the right as illustrated in (44).

(44)

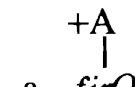

a. $\mathrm{firO}$

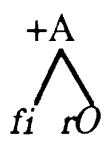

b. $h A r U$<smiles>[AlH][AlH2]</smiles><smiles>[Mg][Mg]</smiles>

Linking

Spreading

fíró 'gourd' hárú 'leaf' Phonetic

\section{Conclusion}

In this paper, we have argued for and shown the following points. First, assimilatory processes within the noun classes trigger certain segmental mutations such as sonorant hardening ( $w$ to $p$ and $r$ to $d$ ). The underlying structure of nasal prefixes in the demonstrative forms is underspecified for place of articulation. Second, the processes in noun class affixation include cluster simplificiation, vowel deletion, compensatory lengthening, and root controlled ATR vowel harmony. 


\section{REFERENCES}

Clements, G.N. 1981. "Akan vowel harmony: a nonlinear analysis." In G.N. Clements (ed.), Harvard Studies in Phonology, Volume 2, pp. 108-177. Bloomington: Indiana ULC.

Clements, G.N. 1985. “The geometry of phonological features." Phonological Year Book 2:225-251.

De Craene, R. 1986. "Le verbe conjugué en tem." Studies in African Linguistics 17:1-37.

Kenstowicz, M., E. Nikiema and M.A. Ourso. 1988. "Tonal polarity in two Gur languages." Studies in Linguistic Sciences 18(2):77-104.

Manessy, G. 1969. Les Langues Gurunsi. Paris: SELAF.

Ourso, M.A. and E.O. Yu. 1987. "The noun class system in Lama." Paper presented at the 18th Conference on African Linguistics, Montreal, Canada.

Ourso, M.A. 1988. "Nominal morphology in Lama: further evidence for lexical phonology." Ms, University of Illinois.

Prost, A. 1964. Lamba. Documents Linguistiques, Université de Dakar.

Pulleyblank, D. 1986. "Underspecification and low vowel harmony in Okpe." Studies in African Linguistics 17:119-153. 
